\title{
Gerhard Lohfink's Interpretative Key to the Sermon on the Mount
}

\author{
MARIAN MACHINEK \\ University of Warmia and Mazury in Olsztyn \\ marian.machinek@gmail.com, ORCID: 0000-0002-1857-1018
}

\begin{abstract}
The purpose of this article is to elicit and analyze the main interpretative key used by the German exegete Gerhard Lohfink in his reading of the Sermon on the Mount. It does not attempt, however, tracing in detail the scholar's interpretation of the individual passages within that biblical text. In Lohfink's understanding, the Sermon on the Mount is not addressed directly to all people but only to those who become disciples of Jesus, and who allow themselves to be gathered as the new Israel. By living according to the message of the Sermon on the Mount, communities of disciples become a light to the world, creating a "contrast society" and thereby demonstrating to the world that human relationships can be shaped in new ways. It is only through this mediation of Christian communities that the world at large can discover the message of the Sermon on the Mount which, in the end, is not a set of abstract moral norms, but rather an indication of the way of life appropriate for the social sphere in which God reigns.
\end{abstract}

Keywords: Sermon on the Mount, Gerhard Lohfink, "contrast society," discipleship, moral rules, the principle of love

Amongst the numerous works of Gerhard Lohfink (b. 1934), the interpretation of the Sermon on the Mount and references to his studies on this piece of Matthew's text continue to hold a prominent position for at least two reasons. The first is the German biblical scholar's indisputable exegetical competence. In the 1980s, Gerhard Lohfink was one of the most renowned exegetes of the New Testament in German speaking countries, and the Sermon on the Mount was one of the central subjects of his research from the very beginning of his career. There is, however, a personal reason as well; it seems no less important than his professional exegetical competence. As he himself states, his decision to resign from the professorship in the field of the New Testament at the prestigious Faculty of Theology in Tübingen in 1986 was dictated by the desire to be fully involved in the life and work of the Catholic Integrated Community (Katholische Integrierte Gemeinde) in Munich. As Lohfink confessed: "There, I have encountered theology anew, more vital and more beautiful than the one I had known so far, but above all theology that grew out of a deep connection between faith and life." Thus, this biographical circumstance, which is

1 Lohfink, Auf der Erde, wo sonst?, 16: "Dort ist mir die Theologie neu begegnet, vitaler und schöner, als ich sie je gekannt hatte - vor allem aber: erwachsend aus einer tiefen Verbundenheit zwischen Glaube und Leben.” 
sometimes considered a reason for the criticism of Lohfink's theological concept, allows him to perceive the Sermon on the Mount in a special way. Lohfink views it as something more than merely a text from the 1st century $\mathrm{AD}$, which can be studied thanks to modern methods of biblical exegesis. From the very outset, Lohfink notices not only the historical significance of the sermon, but also its potential as a life program for Jesus of Nazareth's disciples, not only in biblical times, but also nowadays. This is what determines whether, in the case of the Sermon on the Mount, we are dealing with a program of a more humane form of social life or an unrealistic and ultimately dangerous utopia. ${ }^{2}$

Lohfink's publications vary in the weight of their approach. Some are solid studies with an elaborate critical apparatus, while others are rather pastoral in nature, containing collections of homilies or addressed to a reader with low theological proficiency. Each of them, however, stands as a testament to the author's mastery of exegesis and biblical theology; therefore, there is no need to distinguish between their values to evaluate and compare the worth of each of Lohfink's publications. The purpose of this article is not a meticulous examination of the individual passages of the Sermon on the Mount as interpreted by Gerhard Lohfink but extracting and analyzing the main interpretative key he uses to read this biblical text.

\section{The Sermon on the Mount as a Composition of Jesus' Moral Teachings}

Over the centuries, virtually all the interpreters of the Sermon on the Mount have noticed the unique character of the first of Jesus' Five Discourses in the Gospel of Matthew (Matt 5-7). Referring to this fragment as "the constitution of the Kingdom of God" or the "Magna Carta of Christian morality" indicates the fundamental meaning of this text. Some interpreters saw it as a description of the radical way of life of early Christian communities. Due to its radicalism, the Sermon on the Mount was historically often either spiritualized and understood as private guidelines for moral heroes, or merely as certain images that constitute an invitation to make radical choices, without the intention or commandment to follow any specific conduct. For others, the text had a broader, even universally human, meaning and resembled a code of moral norms addressed to every human being and obliging them to follow it. Such an interpretation could be prompted by the socio-global key, according to which the biblical texts were often read. ${ }^{3}$ The overuse of the first of the abovementioned viewpoints often led to the conclusion that Matthew's text is a proclamation

Lohfink, Auf der Erde, wo sonst?, 20.

Lohfink, Ausgespannt zwischen Himmel und Erde, 83. 
of the more or less utopian ethics of the Kingdom of God, perhaps envisaged only for a short time until the beginning of the Parousia expected to happen soon and therefore referring only symbolically to the inner attitude of Christians today. The second viewpoint sometimes allowed exegetes to infer that the Sermon on the Mount is an example of idealistic, universally human ethics, centered on the values independent of the Christian faith.

As Lohfink stresses, the main problem of these interpretations was, first, disconnecting the words of Jesus in the Sermon on the Mount from the entirety of his message, which itself can be properly understood only in the context of the entire biblical tradition. The New Testament must be seen as the final cleansing and clarification of the contents of the Old Testament faith. As Lohfink emphasizes, Christian theology sees the New Testament as a kind of a "final redaction" (Schlussredaktion) of the Old Testament, which ultimately specifies and complements its message in the light of Christ's teachings. ${ }^{4}$ Thus, there is a kind of "third possibility" between the individualistic interpretation and the socio-political conception of the Sermon on the Mount, and that is exactly what Gerhard Lohfink attempts to develop. ${ }^{5}$

He has no doubt that the Sermon on the Mount as a whole is a composition of Jesus' words made by the redactor(s) of the Gospel of Matthew, which, however, in his opinion, does not completely exclude the possibility that its individual parts reflect the actual utterances of Jesus. ${ }^{6}$ It is also undeniable that this composition was conceived as a collection of all the moral teachings of Jesus. ${ }^{7}$ Unquestionably, the words of Jesus collected in the Sermon on the Mount are not solely a noncommittal instruction. They are entirely directed at action, specific decisions and moral attitudes. In particular, the final part of the text (Matt 7) contains a strong moral impulse. Jesus clearly states that the verbal declarations of the listeners, even manifested by an external recognition of Jesus as Lord, are not enough, and that fulfillment of the will of the Father in Heaven is decisive (Matt 7:21). The parable of the two ways of building a house (Matt 7:24-27), following these words, strengthens this imperative even more. ${ }^{8}$

The fact that the Sermon on the Mount is permeated with the awareness of God's presence and action prevents the reader from one-dimensional concentration on the moral imperative, which could lead to treating it as a kind of radical moralizing.

4 Lohfink, Welche Argumente, 93. This applies not only to the Sermon on the Mount but is an essential element of Lohfink's exegetical method of approaching biblical texts. Whereas the exegesis of older days was heavily focused on reconstructing the sources and earlier layers of the text, now, according to Lohfink, the overall theological significance of its final form (Endtext) is relevant. See: Lohfink, Im Ringen um die Vernunft, 118. See also Lohfink, Ausgespannt zwischen Himmel und Erde, 283.

5 Lohfink, Wem gilt die Bergpredigt?, 12.

6 Lohfink. Das Geheimnis des Galiläers, 60.

7 Lohfink, Wie hat Jesus Gemeinde gewollt?, 47.

8 Lohfink, Im Ringen um die Vernunft, 481-482. See also Lohfink, Die vierzig Gleichnisse Jesu, 229-233 and Lohfink, Wie hat Jesus Gemeinde gewollt?, 71. 
God himself transforms the world by entering history and proclaiming his kingship in Jesus Christ. This transformation is entirely the work of God, but, at the same time, it is fully the work of the human being, and the success of God's plan depends on the commitment of a person who open-heartedly accepts Jesus' prophecies and becomes his disciple. ${ }^{9}$ The union of divine and human action is expressed in the literary form that Jesus often uses in the Sermon on the Mount. It is present in the blessings and appears in the Lord's Prayer as well as in other parts of the Sermon on the Mount. It is about the so-called passivum divinum. If Jesus preaches that the poor in spirit will be offered the kingdom of heaven, the mournful will be comforted, the meek shall inherit the earth (Matt 5:3-10) and those who ask will receive (Matt 7:7), certainly it is not about a kind of natural or historical necessity that would lead to this radical change in the condition of the suffering, but about an undeserved gift from God. ${ }^{10}$ The same applies to the first three petitions of the Lord's prayer where the supplicant asks that God's name be hallowed, his kingdom come, and his will be done in heaven and on earth (Matt 6:9b-10). Thus, the supplicant expects that God will make it happen himself, but he makes the desire for it to happen his own desire. ${ }^{11}$ God's action does not exclude, but presupposes the necessity of human action, as evidenced by the many moral admonishments present in the Sermon on the Mount. They are contained in specific commands as well as in examples and parables. In view of such a multitude of moral teachings in the Sermon on the Mount, it is essential to find a unifying point of reference that will allow the text to be interpreted as a coherent whole. According to Gerhard Lohfink, one can understand the Sermon on the Mount only in the light of the answer to the question about its addressees.

\section{The Addressees of the Sermon on the Mount}

The Sermon on the Mount begins with Jesus looking at the people surrounding him (Matt 5:1). This is not an anonymous crowd. In the preceding verses, Matthew quite precisely defines the origin of Jesus' audience. They form interconnected circles around Jesus, which are nonetheless still distinguishable. Before Jesus begins to teach, his closest disciples approach him. The crowds seem to be in a way distanced in the background. This mention turns out to be important although it may be interpreted in various ways. Two questions must be asked at this point. The first one concerns the role played by these listening crowds. Are they merely some kind of representatives of humankind? They may even constitute a secondary background

\footnotetext{
Lohfink, Ausgespannt zwischen Himmel und Erde, 342.

Lohfink, Gottes Taten gehen weiter, 94-95.

Lohfink, Ausgespannt zwischen Himmel und Erde, 345-346.
} 
for the main scene of the teachings for the disciples. The second question relates to their relationships with the group of the disciples who come closer to listen to Jesus.

To solve these questions, Gerhard Lohfink analyzes the exact nature of the crowds as described by the author of the First Gospel. He lists the regions and urban centers from which the followers of Jesus come: "Large crowds from Galilee, the Decapolis, Jerusalem, Judea and the regions across Jordan followed him." Lohfink assumes that here Matthew uses Mark's text (Mark 3:7-8), which is re-edited in a very significant way. Matthew removes Idumea, Tyre and Sidon from the text of Mark and adds the Decapolis. The mention of the entire land of Galilee from Mark 1:28, through which the news of Jesus' words and deeds spread, changes in a substantial way: "News about him spread all over Syria" (Matt 4:24). ${ }^{12}$ Therefore, the territories populated by Gentiles or those considered as not belonging to the classical territories of Israel were removed. As a result, the map sketched by Matthew does not reflect the geographic and demographic situation in the time of Jesus, but basically coincides with the "map of the fathers" (Landkarte der Väter), i.e., with the area that used to be (according to the rabbinical narrative) the kingdom of David (the Decapolis belonged to this kingdom at that time). ${ }^{13}$ Such a specification of addressees seems to have great importance for the understanding of the text here. The addressees of the Sermon on the Mount, in Matthew's intention, are neither just a handful of the chosen ones, nor are they directly referred to as the whole world, but the whole of Israel gathered again and present in its representatives. Matthew orders the representatives of all historic parts of Israel to walk up to the Mount of Beatitudes. This corresponds to the belief contained in the whole Gospel of Matthew that Jesus, first, is sent to Israel in order for it to become as it had always been meant to be: the salt and light of the world, and the city on the hill. ${ }^{14}$

Such a presumption corresponds to the mountain theme, which is not accidental in Matthew's narrative. Here, Jesus makes his speech from the top of the mount, although the parallel texts in the Gospel of Luke locate similar themes of Jesus' teaching on the plain (Luke 6:20-49, cf. 6:17). This is linked to the main theological thought of the entire Gospel of Matthew and to the spiritual context in which its addressees are rooted. It is the Torah - the Law - which is still God's word for Matthew's community and the most important authority of faith and morality. It can be presumed that for the readers of the Gospel of Matthew, the mountain theme evoked an association with Sinai, the mountain on which the Torah was gifted to Israel. Jesus, as he himself declares, has no intention of annulling it or replacing it with some other teaching, but acts as the final and authoritative (due to his messianic nature) interpreter and teacher of the Torah (Matt 5:17-20). Hence, the posture adopted by Jesus,

\footnotetext{
12 Lohfink, Wem gilt die Bergpredigt?, 24-25.

13 Lohfink, Wem gilt die Bergpredigt?, 28.

14 Lohfink, Wem gilt die Bergpredigt?, 48-49.
} 
which Matthew describes very precisely, is not accidental: it is a sitting position. Such posture in Israel was characteristic of teachers who taught the Torah with authority. Ascending the mountain, sitting, and surrounding oneself with disciples. indicates the significance of what was to happen. ${ }^{15}$

The entire elaborate introduction to the Sermon on the Mount (Matt 4:23-5:1) shows that a triple circle of listeners gathers in front of Jesus, who preaches on the mountain. First, these are the closest disciples. They may be associated with the group of the Twelve. This is "the beginning and center of growth for a renewed, end-time Israel." ${ }^{16}$ The second circle consists of the remaining disciples and sympathizers of Jesus. Finally, the third circle is composed of the representatives of all Israel. They are invited to hear and accept Jesus' sermon and thus become his disciples as well. Therefore, following Lohfink, we can say that the Sermon on the Mount constitutes a "disciple-forming didache." ${ }^{17}$

When we look at how the word "disciple" ( $\mu \alpha \theta \eta \tau \eta \dot{\varphi})$ is used in Matthew's Gospel, and also in the rest of the New Testament writings, we will see that it is one of the key words. A disciple is synonymous with a believer, one who has embarked on the path of listening to and copying the Master as well as actively following him. The gospel accounts leave no doubt as to the difference between Jesus' disciples and those in the rabbinical schools of the time. It is not the disciples who choose Jesus, but he himself appoints them. Nor are they appointed simply to learn the Torah, but because they have heard Jesus' proclamation of the Kingdom of God. ${ }^{18}$ Later in his Gospel, Matthew will define the task that will be given to believers in Jesus. While in the other Gospels, the purpose of the mission is the proclamation of the Good News itself (e.g., in Mark 16:15: "Go into the whole world and preach the Gospel to every creature"), Matthew clarifies the task of the disciples: "Go and make disciples ( $\mu \alpha \theta \eta \tau \varepsilon \dot{\sigma} \sigma \alpha \varepsilon)$ of all nations" (28:19). It is not, therefore, a matter of merely preaching some universal truths, but of preaching in such a way that the listener embarks upon the path of following Jesus and becomes a disciple. It is an interesting detail that Jesus' last missionary command also resounds on a mountain in Galilee (Matt 28:16). By commanding the disciples to make disciples of all nations and to teach them to observe all that he had commanded them (Matt 28:20), Jesus seems to be directly referring to the admonishments in the Sermon on the Mount.

15 Lohfink, Jesus von Nazaret, 270.

16 Lohfink, Braucht Gott die Kirche?, 165, 209: "der Anfang und das Wachstumszentrum des erneuerten, endzeitlichen Israel"; also Lohfink, Jezus von Nazaret, 132. Lohfink sees no problem with the fact that Matthew includes the account of the calling of the apostles only in 10:1-4.

17 Lohfink, Wem gilt die Bergpredigt?, 32: "Die Bergpredigt ist Jünger formende Didache."

18 Lohfink, Wie hat Jesus Gemeinde gewollt?, 43-44. Lohfink points out that this also applies to other New Testament writings. In the Acts of the Apostles, for example, "disciple" is synonymous with a Christian or a member of the community (Gemeindemitglied) of believers. Cf. Lohfink, Jesus von Nazaret, 129. 
To say that the addresses of the Sermon on the Mount are Jesus' disciples, and through them, all of Israel, could easily lead to the conclusion that it represents an exclusive teaching of religious ethics. However, Lohfink strongly objects to the fact that this would imply the exclusion of a universal perspective. There is a grain of truth in the statement that the Sermon on the Mount is a kind of lecture on universal ethics, since "universality is factually inscribed in the concept of the kingdom of God." ${ }^{19}$ Particularity and universality must be seen here in the context of the biblical ideas of mediation and choice. God chooses Israel not because of its uniqueness or impeccability, but on account of his purpose being the salvation of the world. ${ }^{20}$ And this is also where Jesus begins, by reassembling Israel back into a messianic community of disciples. The world will not be able to return to God without the mediation of a community of disciples that the Church constitutes. Lohfink emphasizes that the task entrusted to the community of Jesus' disciples precedes the experience of saving grace. That is why, immediately before the Sermon on the Mount, Matthew includes a reference to Jesus' miracles: "and people brought to him all who were ill with various diseases, those suffering severe pain, the demon-possessed, those having seizures, and the paralyzed; and he healed them" (Matt 4:24). The gift of God's salvation is always preceded by a call to action addressed to man. Before the disciples are called to greater justice, they become witnesses to God's mercy and experience it. In this way, the Sermon on the Mount becomes the teaching which was to form the disciples: each of them individually, but also as a community. Although the disciples are, in a way, the first listeners to the Sermon on the Mount, it applies not only to them, but through their lives it is intended to reach all of Israel, and ultimately, it is to be proclaimed and also shown by the example of their lives to all nations. This is an expression of divine pedagogy which does not wish to bring kingdom of God by violence but only by an appeal directed to human freedom, supported by the witness of those who are already living the reality of the kingdom. Lohfink describes this task of the people of God as a prefiguration which is ultimately supposed to draw all nations toward the reality of the kingdom of God: the community of the disciples is the prefiguration of all Israel, and the newly gathered Israel: the Church that will become truly the people of God is the prefiguration of all nations. ${ }^{21}$

When the renewed Israel finally becomes light and salt for the world - the Old Testament hope of a messianic pilgrimage of people to Zion - expressed by the prophets

19 Lohfink, Wem gilt die Bergpredigt?, 50: "Im Begriff des Reiches Gottes ist auch wirklich Universalität angelegt."

20 Lohfink points out, however, that the choice of Israel is not random at all, but that God chooses the right place where the cultures and influences of that time intersect, the right time when enough painful experience had been gained with the wrong forms of society and the right people, such as Abraham. Cf. Lohfink, Braucht Gott die Kirche?, 49-59.

21 Lohfink, Wem gilt die Bergpredigt?, 51-56. 
and especially by Isaiah (e.g., Isa 2:1-5), will finally be fulfilled (Völkerwallfahrt). ${ }^{22}$ They will come to the light which is radiated by a community living according to God's law. What will attract the nations will be neither military might, numbers, nor other signs of worldly greatness. It can only be the fascination with the disciples' form of communal life, that is, a renewed form of society. ${ }^{23}$ Unlike other revolutions, which always ultimately resort to violence, the revolution associated with God's kingship is not meant to happen that way. God creates a place in the world where his reign will become visible. The renewed and reunited Israel, i.e., the Church, is to become a community which reveals God's will anew to the world through its life. ${ }^{24}$ The disciples of Jesus are to become credible witnesses to a different logic than the one upon which the hitherto existing society is built. They are to give testimony that there is a different, better logic which allows a different society to be built. In this exact way, the concept of society becomes central to Lohfink's understanding of the Sermon on the Mount.

\section{The Community of Jesus' Disciples as a "Contrast-Society"}

Becoming a disciple of Jesus is preceded by an individual decision. This is also true of the whole Bible. Looking at the history of Israel, which began with Abraham's election and his personal decision, Lohfink states: "The possibility of recognizing, implementing and passing on the 'moral law' precisely depends on the fact that in the world there are people who have made the will of God the center of their existence, indeed their sanctity." ${ }^{25}$ This individual decision, however, does not lead to a purely individual relationship with God, but presupposes a communal dimension from the very beginning. The message conveyed by the Sermon on the Mount cannot be understood, much less followed, without a concrete space of human relations within the community of faith ${ }^{26}$ Lohfink, therefore, resolutely opposes any overly

22 Lohfink, Im Ringen um die Vernunft, 105-106. The Gospel of Matthew contains a theme which seems to indicate the Evangelist's conviction that, with the appearance of Jesus, this eschatological journey of peoples has already begun: it is the pericope on mages (Matt 2:1-12). Cf. Lohfink, Gegen die Verharmlosung Jesu, 458-459 and Lohfink, Wie hat Jesus Gemeinde gewollt?, 28-31.

23 Lohfink, Jesus von Nazaret, 106.

24 Lohfink, Ausgespannt zwischen Himmel und Erde, 86: "The disciples are at the service of all people of God, and the people of God are at the service of all peoples." See also Lohfink, Die vierzig Gleichnisse Jesu, 234-235.

25 Lohfink, Braucht Gott die Kirche?, 101: "Daß das «moralische Gesetz» erkannt, getan und weitergegeben werden kann, hängt eben auch davon ab, daß es in der Welt ein Volk gibt, das den Willen Gottes zur Mitte seiner Existenz, ja zu seinem Heiligtum gemacht hat."

26 Lohfink, Wem gilt die Bergpredigt?, 99. Lohfink (Wie hat Jesus Gemeinde gewollt?, 203) notes: "Die Wahrheit des christlichen Glaubens kann deshalb letztlich nur aufleuchten, wenn sie durch die Praxis der Christen einleuchtet." [The truth of the Christian faith can therefore ultimately shine through only if it becomes evident through the practice of Christians.] 
individualistic interpretation not only of this text, but also of Jesus' entire preaching. The individualistic interpretation of the Sermon on the Mount is found, for example, in the works of Eugen Drewermann, which Gerhard Lohfink subjects to harsh criticism (especially in his joint publication with Rudolf Pesch), ${ }^{27}$ Drewermann emphasizes the role of the individual so much that the whole context of Jesus' teaching, especially its rooting in the tradition of Israel and its reference thereto, is passed over as irrelevant, even downright erroneous and thus harmful. But it is precisely such a view that leads to Jesus' ethical references being taken out of context and becoming no more than an enigmatic call to the authenticity of life and action against the social and institutional pressure of the surrounding people. ${ }^{28}$

Jesus certainly did not want to found a new nation or state, nor did he ever call for a political and revolutionary change. However, everything indicates that he wanted to gather around him a community that would establish a new space of life in which people would treat each other differently than in the world surrounding them..$^{29}$ Interpreting Jesus' teachings, however, it is important not only to consider the communal dimension, but also to define properly the shape of that community. According to Lohfink, the interpretations that unilaterally place God's reign in the distant future and speak of the community of the redeemed in heaven are wrong. The new community is not just an object of dreams, a vision that will only come true in the distant future. It has already become a present-day reality, wherever people accept the kingship of God proclaimed by Jesus and are ready to live with others who have made the same decision..$^{30}$ The perception of the community of his disciples as merely a safe environment, separated from the problems of the outside world, in which like-minded people can develop their spirituality, is also erroneous.

The appropriate shape of the community which Jesus wanted does not arise out of nothing, but is based on the experiences of Israel, including painful ones. The history of Israel can also be seen as an experimentation with different forms of communal life, often forced by a situation of political oppression and dependence, with the final form being the one that Jesus adopts and establishes for the community

27 Lohfink - Pesch, Tiefenpsychologie und keine Exegese.

28 Lohfink - Pesch, Tiefenpsychologie und keine Exegese, 43-44. In a commentary on Matthew's Gospel published in 1992, Drewermann insists that no word of the sermon on the Mount can be taken as an ethical requirement, but merely as a description of what becomes possible for someone who really relies on God. Cf. Drewermann, Das Matthäusevangelium, 369.

29 Lohfink, Wie hat Jesus Gemeinde gewollt?, 69-70. Lohfink rejects the views of those who would like to turn the Sermon on the Mount into a set of norms intended directly to build social and state life (as postulated by, for example, Franz Alt, Frieden ist möglich, 9-13), as well as those who, like Max Weber ("Politik als Beruf," 505-560), argue that it is impossible to pursue any politics at all with the Sermon on the Mount or to build a functioning society on this basis.

30 Cf. Lohfink, Jesus von Nazaret, 499. Lohfink (Im Ringen um die Vernunft, 166) argues: "In fact, the kingdom of God in Jesus refers to a specific social reality." 
of his disciples. From the acephalous union of twelve generations characteristic of the Judges' era, through the theocracy associated with the institution of the king and a certain form of subordinate temple-congregations (Tempelgemeinde) existing within the empire, to the union of synagogue-congregations (communes) (Verbund von Synagogengemeinden). ${ }^{31}$ The latter form is not a kind of club or association that meets the specific needs of its members, but a community that embraces all aspects of life. ${ }^{32}$ This seems to come closest to the proper form of the fundamental, mostly small community of believers that Jesus wanted and that was implemented in the original Church.

In his publications, Lohfink takes great care in choosing the German terms that represent a community of people. The closest thing to a core community of disciples is the term Gemeinde, sometimes translated as "commune." It expresses a bond, not only a spiritual one, which arises through individuals opening themselves to the Gospel of Jesus. The term Gemeinschaft very rarely appears in Lohfink's writings. It can be translated as a community, commonwealth. Ultimately, Lohfink chooses the concept of Gesellschaft, which is the broadest among the aforementioned concepts and refers to society as such. For Lohfink, the basic community of Jesus' disciples cannot be confined to itself, but together with other communities, it should form a social structure - society. It is more than just a group of people who have a common goal and meet from time to time. It is a network of communities, which encompasses all aspects of life. It is inevitable that this society of God will sooner or later become a "contrast-society" in relation to its environment (Konstrastgesellschaft). ${ }^{33}$ This definition is one of the key concepts in Gerhard Lohfink's entire concept. In his opinion, the Church, understood as a "contrast-society" created by people dedicated to a way of life different from the pagan one on which most of the structures of this world are built, can only exist in the form of communities capable of revealing the divine version of society to the world.

For the contemporary reader, familiar and reasonably comfortable with the vision of religion as a private matter, and thus viewing the Church as a limited community of people who share the same views, the definition of the Church as a contrast-society is surprising and even disturbing. It is associated either with the intention to establish a closed ghetto for believers, or with an attempt at the appropriation of the existing society by creating a kind of theocracy, imposing religious views on non-believers,

31 Lohfink, Braucht Gott die Kirche?, 137-151.

32 Lohfink, Braucht Gott die Kirche?, 148-149.

33 Lohfink admits that the term "contrast society" is not a biblical concept, but the specific encryption key for the term, in his view, is the imagery of Matt 3:13-16: a town on a hill, the salt of the earth, and the light of the world. Cf. Lohfink, Wie hat Jesus Gemeinde gewollt?, 81-82 and 142. The term Kontrastgesellschaft could also be translated as "society of contrast, a counter- or antisociety" but in my opinion, the translation "contrast-society" seems more accurate. The translation of this term as "an alternative community" in the works of Michał Rychter (Kościót jako społeczność alternatywna, 223-236), seems to be less accurate. 
and other similar activities well-known from the pages of history. It is precisely this fear, present especially in Protestant theology, which gave birth to the concept that contrasts the visible church and its structures with the idea of the "church in the souls." Only such a Church would be the goal of Jesus' teachings, not the visible ecclesiastical structures. The "invisible church," however, confined to the interior of a single human soul, would, as Lohfink points out, mean a betrayal of the realism of the redemption of which the Sermon on the Mount speaks. "Redemption is either specific or there is no redemption at all." ${ }^{34}$ It is not enough for Christians to live as individuals in the bosom of the old society, hoping that they can gradually transform it with their attitude. Such a view underestimates the power of the non-divine structures supporting the old society. It is impossible for an individual to break free from the thought patterns and stereotypes that surround them unless they have access to a real alternative that makes a different way of life possible..$^{35}$ Therefore, a departure, an exodus from the current way of thinking and living is an essential step, which, however, does not have to, and even cannot, be understood in a spatial sense, because it is not about any form of escape. It is by no means about building an isolated ghetto, entirely separate from the rest of the civil society. Remaining in the old society (as its citizen) spatially cannot, however, go hand in hand with the consent to the role assigned to the Church in the framework of certain social theories, postulating the privatization of religion, and thus the "domestication" of the Church, treated only as one of many subareas (Teilbereich) of the whole society (Gesamtgesellschaft). An example of such concept is the social theory of Niklas Luhmann. ${ }^{36}$ The area of religion has its place within it, along with law, science, media, education, and economics. Each of these fields is governed by its own laws. The influence of faith in Christ is limited to the field of religion and should not extend to other areas. In this way, according to Lohfink "society follows its own path, the path of its gods"37 in all these areas since none of them, contrary to the claims of the followers of this vision, is free from ideological implications.

The Church, understood as a contrast society, must remain in the world, but it cannot dissolve into it, losing her own message. It would then become salt without saltiness (Matt 5:13). To prevent this, the Church must create her own space of life. This implies uninterrupted contact and exchange of inspirations with the secular society, but it cannot turn into syncretism, eliminating all differences. ${ }^{38}$ "Precisely

\footnotetext{
34 Lohfink, Gegen die Verharmlosung Jesu, 139: "Erlösung ist konkret oder sie ist überhaupt nicht."

35 Lohfink, Wem gilt die Bergpredigt?, 148.

36 The function fulfilled by the subsystem of religion in the superior system of the whole of society is to provide the sense of purpose, as well as help in solving problems resulting from the loss of the sense of security, or the randomness of existence. See: Luhmann, Die Religion der Gesellschaft, 41-42.

37 Lohfink - Pesch, Tiefenpsychologie und keine Exegese, 105: "geht die Gesellschaft durchaus ihren eigenen Weg, den Weg ihrer Götter."

38 Lohfink, Wem gilt die Bergpredigt?, 150-151.
} 
because the Church does not exist for her own sake, but completely and solely for the world, she must not become the world, but retain her own face."39 Therefore, the Church is not meant to be a kind of environmental lobby nor the headquarters of any religious organization, nor an association preoccupied with moralizing her members. ${ }^{40}$ It must grow into a visible, space of life, a place where God's reign becomes visible and experiential. A space in which people treat one another and relate to one another differently than it is commonly accepted in the surrounding society. This space does not exist outside the secular society but within it because Christ's disciples are nationals and citizens.

In the case of the term "contrast-society" as Lohfink points out, is not about opposing just for the sake of opposition itself. Nor is it an elitist concept that would depreciate the rest of the society. "Contrast" must be interpreted in the context of the Church's mission: it is obliged to be an alternative, exactly because society, as expressed by the image of Jesus in the Sermon on the Mount, describes the role of the disciples as the salt of the earth, a town on a hill and the light of the world (Matt 5:13-14). Precisely because the Church does not exist merely for her own sake, but because of her mission to the world, it cannot be molded into worldly structures and thought patterns. The Church cannot limit herself to social engagement or missionary activity, but must maintain her own outline, in which the divine redemption will manifest itself to the world, reuniting sinners with God. ${ }^{41}$

This context of the message carried by the Sermon on the Mount implies that although Jesus considered the social character of his message, he did not intend to create a new form of community life but drew inspiration from the social message of the Torah. The Torah contains the foundations of legal and social order (Rechts- und Sozialordnung) that was different from the societies surrounding ancient Israel in many key issues. The Bible contains Divine Revelation, but it is also a testimony to the experience gathered over centuries. ${ }^{42}$ This also applies to the way of life according to God's Revelation, not only in an individual, but also in a social context. In the Sermon on the Mount, Jesus does not proclaim any principles defying the Torah, but performs its final eschatological interpretation, simultaneously confirming its binding force (cf. Matt 5:17-19). ${ }^{43}$ With its negation of the obvious connection between civil and religious power, as well as the exploitation of the state's citizens, and, above all, emphasis on the care for the poor, as well as the periodic restoration of social justice (jubilee years), this order is the foundation which - as Lohfink claims - the New

39 Lohfink, Wie hat Jesus Gemeinde gewollt?, 169: "Gerade weil die Kirche nicht für sich selbst, sondern ganz und ausschließlich für die Welt da ist, darf sie nicht zur Welt werden, sondern muß ihr eigenes Gesicht behalten."

40 Lohfink, Im Ringen um die Vernunft, 89.

41 Lohfink, Braucht Gott die Kirche?, 321-322.

42 Lohfink, Welche Argumente, 25.

43 Lohfink, Wem gilt die Bergpredigt?, 109-111. 
Testament communities made reference to. The network of small, distinct, interconnected communities, which the Church of the first century consisted of, is precisely a model of a contrast-society. The concept of the Church as a contrast-society being the primary addressee of the Sermon on the Mount is the interpretative key to the detailed moral principles contained therein.

\section{The Interpretation of the Specific Moral Principles in the Sermon on the Mount}

Even at first glance, it is evident that the Sermon on the Mount contains various kinds of admonishment, implicating, in a way, various specific callings, ranging from the literal imitation of Jesus, pursued by early Christian prophets and travelling missionaries after his resurrection, to the family life of ordinary members of God's people, who remained in their families and homes. There are so many correlations and connections between the moral guidelines relating to various forms of following Christ that it is very difficult to distinguish the ones included in the Sermon on the Mount which are directed only to a specific group of disciples from those directed to the whole of Israel. ${ }^{44}$

\subsection{Who Does Jesus Proclaim to Be Blessed?}

The problem with the interpretation of specific teachings of the Sermon on the Mount begins with the reading of the first part of the text, i.e., the Beatitudes (Matt 5:3-12). They constitute a kind of programmatic element of the whole composition. Lohfink describes them as the Vorhalle (vestibule) through which the road to the center of the Sermon on the Mount leads. ${ }^{45}$ Their contents attract attention because Jesus speaks of the happiness of those who, due to poverty, being pushed to the fringes of society, sadness, suffered injustice and lack of mercy, experience something that is usually an obstacle on the way to man's happiness.

It is in this context that the accusation of an unrealistic utopia or even cynicism is often made: instead of dealing with suffering, those who suffer are comforted by showing them the prospect of posthumous relief. First, Lohfink points out that the macarisms in the Gospel of Matthew sound different than the parallel text in the Gospel of Luke, where poverty, sorrow and weeping seem to literally describe social problems, and the repeated word "now" ( $v \tilde{v} v)$ emphasizes that it is about the current state of people affected by these problems (cf. Luke 6:20-23). In Matthew's

\footnotetext{
44 Lohfink, Wie hat Jesus Gemeinde gewollt?, 46-47 and 56-57.

45 Lohfink, Ausgespannt zwischen Himmel und Erde, 82.
} 
beatitudes, the poor become "poor in spirit" and the hungry - "those who hunger and thirst for righteousness." Although poverty is not underestimated here because it is associated with measurable human suffering, Jesus does not bless poverty itself, but the poor, and he does not bless hunger, but the hungry. He blesses them precisely because their poverty and hunger will be averted. It is not only a presage of the ultimate fulfilment of human longings sometime after the end of life. Neither is it a presage of an idyllic world. In Lohfink's conviction, these declarations become clear only when related to the context of the community of disciples as the seed of the contrast-society. It is in this space of a community of disciples determined to follow Jesus that the blessings can be fulfilled now before they are fulfilled in end times. Even if poverty, hunger, and sadness also affect the disciples, they are different than the ones in the surrounding world: it is the poverty of those who put their property at the disposal of others, it is a hunger for righteousness, it is sadness in the face of everything that disturbs the final revelation in the world of God's kingship. ${ }^{46}$ All these and other serious human miseries can be averted; desires and longings can be satisfied by a new form of life in a community that draws its strength from the conviction that God's kingship enters man's existence with a new power in Jesus. ${ }^{47}$

In Jesus' mind, as Lohfink claims, it is the Church that is historically supposed to be the place where the eschatological consolation, abundantly bestowed by God, will become visibly present in the here and now. "The Church is the messianic place of God's consolation in the world." ${ }^{48}$ At the same time, the Church is supposed to become a place where the transformation of the world, started by Jesus and in Jesus, will be continued.

\subsection{A Call for Forgiveness and Renunciation of Violence}

The issue of renouncing violence and forgiving one's wrongdoers occupies a lot of space in the moral admonishments of the Sermon on the Mount, so it can hardly be considered marginal. The following antitheses refer to it: the first (Matt 5:21-26), the fifth (5:38-42), and the sixth (5:43-48); it also appears in the Beatitudes (especially in the final verses: 5:10-12); it is the culmination of the Lord's Prayer (6:12, 14-15), and it also resounds in the golden rule (7:12). Therefore, even if one would like to contradict the statement that here we are dealing with Jesus' ipsissima vox, these teachings certainly reflect his ipsissima intentio. ${ }^{49}$

There is no doubt: Jesus commands the renunciation of vengeance, as well as the proactive love of your neighbor, even your wrongdoer. Obviously, the form in

\footnotetext{
46 Lohfink, Gottes Volksbegehren, 155-159.

47 Lohfink, Ausgespannt zwischen Himmel und Erde, 83-86.

48 Lohfink, Gottes Taten gehen weiter, 98: "Die Kirche ist der messianische Ort des Trostes Gottes in der Welt."

49 Lohfink, Wem gilt die Bergpredigt?, 43.
} 
which Jesus expresses his teaching may be considered radical, which does not diminish the importance of his command in any way. Jesus does not speak of the difficulties arising from circumstances and dependencies, but instead he reaches to the roots: this is the meaning of the word "radical" (radix - root). ${ }^{50}$ At the same time, he illustrates his prohibition of violence by referring to various situations associated with hostility towards your neighbor: whether in the form of anger and a simple conflict, or greater or lesser violence and hatred. Evidently, the specific examples enumerated by Jesus do not constitute, as Lohfink emphasizes, anything like a "cooking recipe" (Kochrezept), from which one can build a code of specific moral norms, as if from individual blocks. ${ }^{51}$ Rather, they are indications that the love of your neighbor and willingness to forgive must be sincere if they are to be genuine. They always point to one conclusion: forgiveness and reconciliation are the only right path. In the new reality of God's kingdom, there is no time left to pursue one's claims. Jesus speaks about this directly, as well as in small but very distinct images and parables, such as the parable of the way to court (Matt 5:25-26). ${ }^{52}$

Just as in the reference to the entire Sermon on the Mount, especially in the case of the command to renounce violence, Lohfink states that it is a great deficiency of the discussion of this text that questions are not consistently asked about its addressees. The original context of the passages concerning the renunciation of violence was the instructions for the disciples sent on a mission by Jesus. Without a walking stick and sandals (cf. Matt 10:10), the disciples were defenseless and, in a way, forced to renounce violence. For those around them, this had to be a clear signal of their peaceful attitude..$^{53}$ This does not mean total passivity towards violence, but rather a prophetic provocation, a sign of an attitude free from opposition to the omnipresence of revenge and the use of brutal force. ${ }^{54}$ Turning the other cheek to the one who slaps the right cheek ${ }^{55}$ (Matt 5:39) is firstly a clear contrast to the attitude of various groups of "God's fighters" in Jesus' time (e.g., the zealots), who preached a diametrically different attitude: to violence you should react with the same violence; no aggression and no insult can be left without the same answer.

Naturally, the command to renounce violence is not limited to the original context of the missions of early Christian missionaries, as there exist many other forms of following Jesus apart from this. By calling us to renounce violence and to forgive our wrongdoers, Jesus expresses his opposition to succumbing to the primal

\footnotetext{
Lohfink, Jesus von Nazaret, 279. Also Lohfink, Braucht Gott die Kirche?, 91.

Lohfink, Gegen die Verharmlosung Jesu, 100-102.

Lohfink, Die vierzig Gleichnisse Jesu, 179-180.

Lohfink, Wem gilt die Bergpredigt?, 47.

Lohfink, Im Ringen um die Vernunft, 169.

55 A blow to the right cheek, i.e. not with an open hand, but with a wrist, was not only a symbol of violence in the Semitic culture of those times, but also a means of insult to the party receiving the blow, and such an insult could not go unavenged. Cf. Lohfink, Jesus von Nazaret, 120-123.
} 
human aspiration to gain and exercise power over others as well as to achieve importance and influence in society. ${ }^{56} \mathrm{~A}$ single believer, despite their moral effort and good will, is unable to properly understand and persevere in the message of the Gospel. It is the community forming together with other communities the people of the new covenant - the Church - that directs a single believer towards the Gospel anew. ${ }^{57}$ There are rivalries and fights over who is greater and more important, both outside the community of Jesus' disciples as well as within it. United around one common Father in heaven and his coming kingship in Jesus, the new Israel does not consist solely of people with extraordinary moral values. Just as it is not built on kinship, inheritance, talents, or state structure, neither is it based on man's good will alone. ${ }^{58}$ The Church is made up of sinners who, by accepting the Gospel, are to live in a way that is an alternative to that of older societies. It is for this reason that forgiveness and reconciliation become attitudes that determine the credibility of the Church. ${ }^{59}$ Where Jesus' disciples allow themselves to form a new family, there is no longer room for the old way of life full of vengeance, competition and contempt. Otherwise, God's plan to create a contrast-society, a new people who, despite living among other peoples, do not inherit their characteristics, such as authoritarian kings, territories and constant fighting for power and importance; it will remain a utopia. Therefore, forgiving our wrongdoers does not refer first to our great wrongs and cruelty we suffer in global disasters, but to everyday life in a community of disciples. ${ }^{60}$

The question remains: in what sense does the call to renounce violence apply to relationships with people outside the community of believers? Christian communities live in pluralistic societies, composed partly (sometimes mostly) of people who do not belong to these communities. The Sermon on the Mount does not refer directly to the rules governing secular societies, nor does it contain the norms by which these societies should be organized. If a society does not fully accept the magnitude of God's kingdom, it must have at its disposal coercive measures to enforce its law. This means the presence of a legitimized and channeled use of force. Despite this, the attitude of Christian communities, renouncing violence in their mutual relations, may play an important role in relation to secular societies. At this point Lohfink points out various possibilities. The first is the rejection of violence, an action having the nature of a sign. In the past, many Christians adopted this attitude. ${ }^{61}$ Lohfink admits that there was no undisputed and universally binding pacifism in

56 Lohfink, Ausgespannt zwischen Himmel und Erde, 101.

57 Lohfink - Pesch, Tiefenpsychologie und keine Exegese, 109.

58 Lohfink - Pesch, "Volk Gottes als «Neue Familie»", 239.

59 Lohfink, Im Ringen um die Vernunft, 298. Lohfink, Wie hat Jesus Gemeinde gewollt?, 170.

60 Lohfink notes that when the Greek word for "brother" (å $\delta \varepsilon \lambda \varphi o ́ c)$ is encountered in the Gospel of Matthew, it is used to describe not only familial relations, but also brothers in faith or the disciples of Jesus. However, there is no mention of an overwhelming sentiment of brotherhood in the sense of humanity shared among all people. See: Lohfink, Im Ringen um die Vernunft, 485.

61 Lohfink, Wem gilt die Bergpredigt?, 60-61. 
the early Church although some early Christian writers were categorically opposed to Christians joining any army. ${ }^{62}$ The second possibility is an approximate fulfillment of Christ's precepts by minimizing violence. Certainly, Christians are also allowed to hold government offices - this is the third possibility - and it involves the use of state coercive measures against criminals. After all, it cannot be the case that Christians gratefully benefit from social order and the common good, protected by state means of coercion, but leave the application of these measures to others. These different possibilities exist side by side as plausible and ethically acceptable choices. However, the best service that believers in Christ can render to a secular society is, as Lohfink emphasizes, the construction of living communities in which relationships are established not only using the spirit of the Sermon on the Mount, but by adhering to its message, especially Jesus' call to renounce violence. ${ }^{63}$

\subsection{Relinquishing Unnecessary Worries}

When the detailed moral guidelines of the Sermon on the Mount are seen not through the lens of an ethical program concerning every human being, or even a political concept according to which social relations in every country should be regulated, but as precepts for the community of disciples, the way of understanding a particular moral guideline also changes, concerning the issue of possessions, wealth and striving for worldly goods. It primarily teaches about permanent goods and cautions against unnecessary worries (Matt 6:19-34). This is the second area in which the community of Christ's disciples, which is the Church, must become a contrast-society which through its practice of life shows a logic different from the one generally adopted.

As Lohfink claims, also in reference to these texts, the primary context is the situation of those disciples who are sent to preach the Good News. The command to strip oneself of everything, even a staff that could have been used for defense (Matt 10:9-10), which is contained in the Gospel of Matthew, should not be understood in terms of a philosophical ideal of asceticism or extreme radicalism. Rather, as was the case with the rejection of violence, it is a feature that sets apart the disciples from the zealots who were a movement of men calling for armed opposition against the Roman occupation authorities. They, too, had the habit of going from place to place to express their ideas and gain followers. ${ }^{64}$ Jesus' disciples are to reject not only violence, but also any intrusive, excessive concern for all worldly goods: even those

62 Obviously, some Early Christian authors, as well as certain communities of this epoch, considered military service to be utterly incompatible with the Christian way of living. Cf. Lohfink, Wie hat Jesus Gemeinde gewollt?, 194.

63 Lohfink, Wem gilt die Bergpredigt?, 63. Also see Lohfink, Czy Jezus głosił utopię?, 57-59.

64 Lohfink, Das Vaterunser neu ausgelegt, 21. See also: Lohfink, Im Ringen um die Vernunft, 169. Lohfink, Gegen die Verharmlosung Jesu, 113-114. 
perceived as essential. This concern, or even existential fear, is one of the key characteristics of an unredeemed human being. ${ }^{65}$

Historically, the fragment of the Sermon on the Mount concerning unnecessary worries (Matt 6:25-34) has been criticized as an expression of economic naiveté, an invitation to be an aesthete: someone who leaves work to others and lives at their

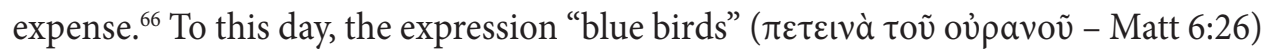
refers to people who live at the expense of society. According to Lohfink, this interpretation is a direct result of the context-free reading of the Sermon on the Mount as a philosophical pondering directed at all humankind. True Christian freedom from superfluous concerns relates first of all to trust in the Father in heaven, but at the same time - with great realism - to the context of a brotherly community, which helps in satisfying the fundamental needs of life. ${ }^{67}$ The disciples who are called to preach the Gospel directly and intensively can primarily and solely care for the Kingdom of God and its justice since they are supported by others who are not called to perform this ministry. Taking advantage of their assistance, however, they also provide support for them in faith and fidelity to the Gospel of Jesus. In this way, these mutual bonds enable their intense apostolic work. ${ }^{68}$

The fourth petition of the Lord's Prayer, namely the request for bread (Matt 6:11), should also be understood in this context. Lohfink is convinced that its original Sitz im Leben was precisely the situation of the Gospel preachers who, like Jesus, travelled around Palestine and announced the coming of the Kingdom of God. ${ }^{69}$ They were not to store up for themselves any goods because this would undermine dynamism and make it difficult to travel. Instead, they were to ask for bread: for the next day only. This is how Lohfink understands the word ह̇лıov the ancient Greek apart from the Lord's prayer. It is not about providing a continuous supply of food, but about a request on that day in the evening when someone took them in, fed them and put them up (the "next day" began in Israel just after sunset)..$^{70}$ This request is not intended to contrive, with God's help, in some magical way, the benevolence of strangers. Nor is it an expression of the expectation that the necessary nourishment will be provided by some miraculous, direct intervention of God. Jesus simply assumes that in Palestine, in addition to the disciples committed to preaching, there are other disciples living in families, as well as sympathizers,

65 Lohfink, Wem gilt die Bergpredigt?, 127.

66 Lohfink, Wem gilt die Bergpredigt?, 128-129.

67 Lohfink, Ausgespannt zwischen Himmel und Erde, 246-247.

68 Lohfink, Braucht Gott die Kirche?, 172-174.

69 Lohfink, Das Vaterunser neu ausgelegt, 21.

70 Lohfink, Das Vaterunser neu ausgelegt, 24-26. Such an interpretation seems to be supported by the words uttered by Jesus in the later part of the Sermon on the Mount: "Therefore do not worry about tomorrow, for tomorrow will worry about itself. Each day has enough trouble of its own" (Matt 6:34). See: Lohfink, Im Ringen um die Vernunft, 293-295. Also cf. Lohfink, Jesus von Nazaret, 116-118. 
the healed, the curious, and thus those who are willing to put up the preachers. The community of disciples is not a hermetically closed group, but gathers people of various provenance, with a different way of life and also with a diverse commitment to the cause of Jesus. Here Lohfink emphasizes the importance of various forms of belonging to the new family that Jesus is building. ${ }^{71}$ This does not mean diminishing the radicalism of Jesus' call to his listeners. Only complete openness to the reality of the Kingdom of God is the correct attitude. Every disciple is called upon to be perfect

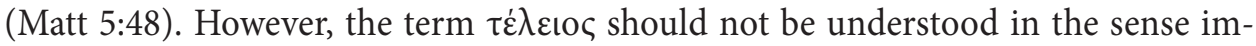
parted to it by Hellenistic ethics. This is not impeccability in the practice of virtues,

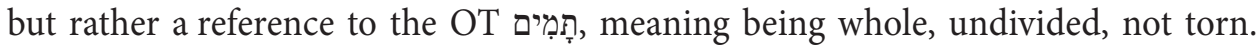
The disciple should be wholeheartedly committed to the Kingdom of God. ${ }^{72}$ This is not meant to be an act of moral heroism, but of devotion based on a fascination with finding the treasure of the kingdom of God. It is this indivisibility (Ungeteiltheit) that is at the heart of Jesus' radicalism as expressed in the Sermon on the Mount. Radicalism is not only an attitude which is required here, but above all, an attitude that is made possible by God's action surpassing one's strength. ${ }^{73}$

\section{Conclusion}

Admittedly, the interpretation of the Sermon on the Mount by Gerhard Lohfink is highly suggestive, because it not only allows one to understand this unique text, but also gives a coherent view of the whole of Jesus' teaching, and places it convincingly within the entire tradition of Israel. The key to a proper understanding of the indications of this biblical text is the concept of a contrast-society, understood as an environment in which it is possible to practice Jesus' moral principles. The attitude of forgiveness is of particular importance here, but it is also a place where people abandoned and forsaken (e.g., by a spouse) can find friendly relationships and need not fear loneliness. Further, it is a place where there should be no people without a livelihood; so it is a place of mutual sharing. The concept of a contrast-society is the basis for Lohfink's criticism of the contemporary Church. Although the starting

71 While highlighting various forms of belonging to the circle of Jesus' disciples, Lohfink also emphasizes, that, in the Gospels, even when somebody does not officially belong to this group, this does not automatically mark them as of lacking faith. Every person who accepts the words of Christ regarding the kingdom of God, coming in the person of Jesus Christ, has their own calling. Cf. Lohfink, Jesus von Nazaret, 144. Also cf. Lohfink, Ausgespannt zwischen Himmel und Erde, 349.

72 Lohfink, Jesus von Nazaret, 147-148, and 502-503; also Lohfink, Braucht Gott die Kirche?, 173-174, and 274-277.

73 See also a detailed analysis of the notion of radicalism in the context of the teachings of Jesus in: Lohfink, Wem gilt die Bergpredigt?, 65-98, with summarizing theses on pages 97-98. 
point seems to be the structures of the Church in her own homeland, this can be related to the situation of the entire contemporary Church. However, this is not a form of criticism that is often found in the contemporary public discourse. Lohfink avoids shallow criticism, which makes it worth taking a closer look at his opinion. The belief that it is possible to change the world with moral appeals alone is an illusion. This will only be possible when the Church, as a new society under the rule of God, becomes a clear alternative to the dominant models of social life in the modern world. Ultimately, as Lohfink emphatically states, the Church "can only transform the world by becoming herself a redeemed and transformed world." 74

In the face of contemporary phenomena, such as the loss of the importance of the Church and Christianity in formerly Christian countries, the indifference or even hostility of many societies towards believers, not to mention the persecution of Christians, Lohfink confesses: "I sometimes wonder whether such a development is good or bad. It is certainly bad as people are isolated, persecuted, hurt and even killed because of their faith. It could well be good because Christians will have to rethink their beliefs under these conditions. It is no longer something natural. It demands a distance from illusory patterns in life, from erroneous behavior, and from false 'idols.' It demands a new life based on trust in God. It demands a sovereign human decision. This is certainly something good." ${ }^{\prime 5}$

To those critics who emphasize the overly idealistic character of the "contrast-society" proposal in the context of widespread secularization, Gerhard Lohfink replies asking "if not today, then when?," which is the title of one of his books. ${ }^{76}$

Translated by Grzegorz Knyś

\section{Bibliography}

Alt, F., Frieden ist möglich. Die Politik der Bergpredigt (München - Zürich: Piper 1990).

Drewermann, E., Das Matthäusevangelium. I. MT 1,1-7,29. Bilder der Erfüllung (Olten: Walter 1992).

Lohfink, G., Gottes Taten gehen weiter. Geschichtstheologie als Grundvollzug neutestamentlicher Gemeinden (Freiburg - Basel - Wien: Herder 1985).

74 Lohfink - Pesch, Tiefenpsychologie und keine Exegese, 105; "nur dadurch Welt verändern kann, daß sie selbst erlöste und veränderte Welt wird."

75 Lohfink, Der christliche Glaube erklärt in 50 Briefen, 162: "Ich frage mich manchmal, ob diese ganze Entwicklung schlimm oder gut ist. Schlimm ist auf jeden Fall, wenn Menschen wegen ihres Glaubens isoliert, benachteiligt, verletzt oder umgebracht werden. Gut aber könnte sein, dass Christen sich unter diesen Umständen neu auf ihren Gauben besinnen müssen. Er ist eben längst keine Selbstverständlichkeit mehr. Er verlangt Distanz zu falschen Leitbildern, falschen Verhaltensweisen, falschen Göttern. Er verlangt eine bewusste Existenz aus dem Glauben. Er verlangt die eigene Entscheidung. Und das ist etwas Gutes." 
Lohfink, G., Wem gilt die Bergpredigt? Zur Glaubwürdigkeit des Christlichen (Freiburg - Basel Wien: Herder 1993).

Lohfink, G., Wie hat Jesus Gemeinde gewollt? (Freiburg - Basel - Wien: Herder 1993).

Lohfink, G., Braucht Gott die Kirche? Zur Theologie des Volkes Gottes (Freiburg - Basel - Wien: Herder 1998).

Lohfink, G., Gottes Volksbegehren. Biblische Herausforderungen (München - Zürich - Wien: Neue Stadt 1998).

Lohfink, G., "Jesus und die Kirche," Handbuch der Fundamentaltheologie. III. Traktat Kirche (eds. W. Kern - H.J. Pottmeyer - M. Seckler) (Stuttgart: UTB 2000) 27-64.

Lohfink, G., Auf der Erde, wo sonst? Ein theologisches Tagebuch (Bad Tölz: Urfeld 2003).

Lohfink, G., Czy Jezus głosił utopię? (trans. E. Pieciul-Karmińska) (Poznań: W drodze 2006).

Lohfink, G., Das Vaterunser neu ausgelegt (Bad Tölz: Urfeld 2007).

Lohfink, G., Welche Argumente hat der neue Atheismus? Eine kritische Auseinandersetzung (Bad Tölz: Urfeld 2008).

Lohfink, G., Beten schenkt Heimat. Theologie und Praxis des christlichen Gebets (Freiburg im Breisgau: Herder 2010).

Lohfink, G., Jesus von Nazaret - Was er wollte, wer er war (Freiburg - Basel - Wien: Herder 2011).

Lohfink, G., Gegen die Verharmlosung Jesu. Reden über Jesus und die Kirche (Freiburg - Basel Wien: Herder 2013).

Lohfink, G., Heute - wann sonst? Unangepasstes über Gott und die Welt (Stuttgart: Katholisches Bibelwerk 2014).

Lohfink, G., Im Ringen um die Vernunft. Reden über Israel, die Kirche und die Europäische Aufklärung (Freiburg - Basel - Wien: Herder 2016).

Lohfink, G., Am Ende das Nichts? Über Auferstehung und Ewiges Leben, 5 ed. (Freiburg - Basel Wien: Herder 2018).

Lohfink, G., Der christliche Glaube erklärt in 50 Briefen (Freiburg im Breisgau: Herder 2018).

Lohfink, G., Das Geheimnis des Galiläers. Ein Nachtgespräch über Jesus von Nazaret (Freiburg Basel - Wien: Herder 2019).

Lohfink, G., Die vierzig Gleichnisse Jesu, 4 ed. (Freiburg - Basel - Wien: Herder 2020).

Lohfink, G. - Pesch, R., Tiefenpsychologie und keine Exegese. Eine Auseinandersetzung mit Eugen Drewermann (Stuttgart: Katholisches Bibelwerk 1987).

Lohfink, G. - Pesch, R., "Volk Gottes als «Neue Familie»," Surrexit Dominus vere. Die Gegenwart des Auferstandenen in seiner Kirche. Festschrift für Erzbischof Dr. Johannes Joachim Degenhardt (eds. J. Ernst - S. Leimgruber) (Paderborn: Bonifatius 1995) 227-242.

Luhmann, N., Die Religion der Gesellschaft (Frankfurt am Main: Suhrkamp 2000).

Rychert, M., Kościół jako społeczność alternatywna. Teologia królestwa Bożego według Gerharda Lohfinka (Toruń: Wydawnictwo Naukowe UMK 2009).

Weber, M., "Politik als Beruf," M. Weber, Gesammelte politische Schriften, 3. ed. (Tübingen: Mohr 1971) 505-560. 
